\title{
Analysis and Control of the Measurement of the University Students’ Ability
}

\author{
D. $\mathrm{Fu}$ \\ School of Humanities, Jiangxi University of Traditional \\ Chinese Medicine \\ Nanchang, China
}

\begin{abstract}
We explored the methods of extension evaluation method in the application of innovation ability measurement for university students. This paper used both statistical analysis and comprehensive evaluation analysis carried out by statistical analysis software SPSS19.0 and MATLAB7.0, aimed to study a evaluation system which could be used to measure the innovation ability of university students. According to the former study, the structural equation model of university students' innovation ability suggested there were five factors: innovation knowledge, innovation unconsciousness, innovation thinking, innovation behavior and innovation personality. The weight coefficient of the five factors were $0.2,0.2,0.28,0.12$ and 0.2 . The score of the innovation knowledge and innovation personality of the students in the Chinese medicine scientific research class was better than the students in the non Chinese medicine scientific research practice class. The results can provide a guide for the innovation ability measurement of university students.
\end{abstract}

Keywords-university students; measurement; analysis and control

\section{INTRODUCTION}

The extension is the science which could study the possible expend and innovation of a thing. Multi-index comprehensive evaluation based on the theory of extension is a new decision method for multivariate quantitative [1]. By using extension comprehensive evaluation method, multi-index evaluation can be transformed into a decision single objective, and to measure by the quantitative value [2]. At present, extension comprehensive evaluation method can be used in the level of product quality comprehensive evaluation and scientific and technological innovation ability evaluation and other aspects which can be applied [3]. This paper used the extension comprehensive evaluation method as measuring tools to study the innovation of 167 university students.

\section{RESEARCH METHODS}

167 subjects came from a medical university. Among them, the students of the Chinese medicine scientific research class were 82, the students of Traditional Chinese medicine majors and non Chinese medicine scientific research practice class were 32, and the humanities students were 53 . The extension comprehensive evaluation method and factor analysis were applied to measure the students' innovation ability.

\author{
Z.F. He \\ School of Humanities, Jiangxi University of Traditional \\ Chinese Medicine \\ Nanchang, China
}

\section{RESUlTS AND DiscUSSION}

According to the extension comprehensive evaluation method, combined with questionnaire investigation and expert evaluation method, evaluation index and weight of innovation ability of medical students were informed, which was shown in table.1.

The Comparison of AVOVA results of three groups of students was shown in table.2.

TABLE I. THE INNOVATION ABILITY ANOVA ANALYSIS.

\begin{tabular}{|c|c|c|c|c|c|c|}
\hline \multicolumn{2}{|l|}{ group } & $\mathbf{n}$ & Mean & $\begin{array}{l}\text { Standard } \\
\text { deviation }\end{array}$ & $\mathbf{F}$ & $\mathbf{p}$ \\
\hline \multirow{4}{*}{$\begin{array}{l}\text { Innovation } \\
\text { knowledge }\end{array}$} & 1 & 82 & 3. 66 & .628 & 19. 319 & .000 \\
\hline & 2 & 32 & 3.15 & .676 & & \\
\hline & 3 & 53 & 3. 27 & .497 & & \\
\hline & total & 167 & 2.95 & .663 & & \\
\hline \multirow{4}{*}{$\begin{array}{l}\text { Innovation } \\
\text { unconsciousness }\end{array}$} & 1 & 82 & 3.06 & .674 & .170 & .844 \\
\hline & 2 & 32 & 2. 99 & .603 & & \\
\hline & 3 & 53 & 3.01 & .443 & & \\
\hline & total & 167 & 3.03 & .593 & & \\
\hline \multirow{4}{*}{$\begin{array}{l}\text { Innovation } \\
\text { thinking }\end{array}$} & 1 & 82 & 3.20 & .608 & 2. 019 & .136 \\
\hline & 2 & 32 & 3.36 & .379 & & \\
\hline & 3 & 53 & 3.37 & .448 & & \\
\hline & total & 167 & 3.29 & .526 & & \\
\hline \multirow{4}{*}{$\begin{array}{l}\text { Innovation } \\
\text { thinking }\end{array}$} & 1 & 82 & 1. 80 & .355 & 1. 632 & .199 \\
\hline & 2 & 32 & 1. 91 & .435 & & \\
\hline & 3 & 53 & 1. 78 & .261 & & \\
\hline & total & 167 & 1. 81 & .347 & & \\
\hline \multirow{4}{*}{$\begin{array}{l}\text { Innovation } \\
\text { personality }\end{array}$} & 1 & 82 & 3.96 & .495 & 4. 077 & .019 \\
\hline & 2 & 32 & 3.20 & .500 & & \\
\hline & 3 & 53 & 3.10 & .427 & & \\
\hline & total & 167 & 3.57 & .484 & & \\
\hline \multirow[t]{4}{*}{ The sum } & 1 & 82 & 3.95 & .398 & 7. 405 & .001 \\
\hline & 2 & 32 & 3. 12 & .271 & & \\
\hline & 3 & 53 & 3.15 & .205 & & \\
\hline & total & 167 & 3.05 & .337 & & \\
\hline
\end{tabular}

Note: $* P<0.05 ; * * P<0.01$

The Table. 2 results shows, Chinese medicine research practice class and non Chinese medicine scientific research practice class student has the remarkable difference in the sense of innovation, creative personality and creative quality score of three aspects. That is to say, the innovation consciousness, innovation personality and innovative quality score of three of 
the practice of scientific research students better than the non Chinese medicine scientific research practice class.

At the same time, in order to protect the scientific and accuracy of the research results, the study referenced the criterion validity of psychological measurement to verify the results, which was showed in table.3.

TABLE II. THE EVALUATION INDEX AND WEIGHT OF INNOVATION ABILITY.

\begin{tabular}{|c|c|c|c|}
\hline $\begin{array}{l}\text { One } \\
\text { class } \\
\text { index }\end{array}$ & $\begin{array}{c}\text { The } \\
\text { weight } \\
\text { coefficie } \\
\text { nt }\end{array}$ & Two level index & $\begin{array}{c}\text { The } \\
\text { weight } \\
\text { coefficie } \\
\text { nt }\end{array}$ \\
\hline \multirow{4}{*}{$\begin{array}{l}\text { Innovati } \\
\text { on } \\
\text { knowled } \\
\text { ge }\end{array}$} & \multirow{4}{*}{0.20} & The general level of knowledge & 0.21 \\
\hline & & $\begin{array}{l}\text { The level of professional } \\
\text { knowledge }\end{array}$ & 0.21 \\
\hline & & $\begin{array}{l}\text { The level of professional } \\
\text { knowledge }\end{array}$ & 0.34 \\
\hline & & $\begin{array}{l}\text { The innovation of knowledge } \\
\text { level }\end{array}$ & 0.24 \\
\hline \multirow{3}{*}{$\begin{array}{l}\text { Innovati } \\
\text { on } \\
\text { unconsci } \\
\text { ousness }\end{array}$} & \multirow{3}{*}{0.20} & A strong desire for knowledge & 0.41 \\
\hline & & Wide interests & 0.26 \\
\hline & & Rich imagination & 0.33 \\
\hline \multirow{3}{*}{$\begin{array}{l}\text { Innovati } \\
\text { on } \\
\text { thinking }\end{array}$} & \multirow{3}{*}{0.28} & Unique thinking & 0.33 \\
\hline & & Fluency thinking & 0.33 \\
\hline & & The flexibility of thinking & 0.34 \\
\hline \multirow{5}{*}{$\begin{array}{l}\text { Innovati } \\
\text { on } \\
\text { behavior }\end{array}$} & \multirow{5}{*}{0.12} & $\begin{array}{l}\text { The experimental operation } \\
\text { ability }\end{array}$ & 0.34 \\
\hline & & The number of published papers & 0.28 \\
\hline & & $\begin{array}{l}\text { Chairing or participating in the } \\
\text { project case }\end{array}$ & 0.13 \\
\hline & & The awards & 0.13 \\
\hline & & Other results & 0.12 \\
\hline \multirow{8}{*}{$\begin{array}{l}\text { Innovati } \\
\text { on } \\
\text { personal } \\
\text { ity }\end{array}$} & \multirow{8}{*}{0.20} & The lofty ideal and firm faith & 0.15 \\
\hline & & The humanitarian spirit & 0.05 \\
\hline & & The spirit of friendly cooperation & 0.05 \\
\hline & & Criticism and inheritance & 0.15 \\
\hline & & The spirit of exploration & 0.15 \\
\hline & & Professionalism & 0.15 \\
\hline & & $\begin{array}{l}\text { Seeking truth and the spirit of } \\
\text { resistance to compression }\end{array}$ & 0.15 \\
\hline & & The spirit of self-confidence & 0.15 \\
\hline
\end{tabular}

TABLE III. CRITERION RELATED VALIDITY.

\begin{tabular}{lrccc}
\hline & Mean & $\begin{array}{c}\text { Standard } \\
\text { deviation }\end{array}$ & $\begin{array}{c}\text { The } \\
\text { correlation } \\
\text { coefficient }\end{array}$ \\
\hline $\begin{array}{l}\text { Self }- \\
\text { level(n=167) }\end{array}$ & Assessment & 2.95 & .44 & $0.75^{* *}$ \\
$\begin{array}{l}\text { The } \\
\text { rating(n=167) }\end{array}$ & teacher & 2.98 & .41 & \\
\hline
\end{tabular}

Some researchers think that, when two people at the same time using two different evaluation methods to measure a personal work attitude, and the correlation coefficient of the two evaluation of is very high, for example: 0.80 , then similar evaluation method can replace the complicated evaluation method[4]. Therefore, when the criterion validity is more than
0.8, which indicates that the two test results are highly consistent, so they can replace with each other. The results of the self assessment of university students and the teacher evaluation in this study is high correlative, and the correlation coefficient is 0.75 , close to 0.8 . Therefore, the study believes that the university students' innovation ability evaluation in the future can use the students' self evaluation with extension evaluation method instead of the teacher evaluation method in some extent, and it can greatly improve the efficiency of university students' innovation ability and quality evaluation [5].

\section{CONCLUSIONS}

The improved AHP and multi index comprehensive extension method could be well applied in our medical students innovation research of quality evaluation system, and the results were more comprehensive and objective. It was in line with the actual situation of higher schools, especially the higher medical colleges and universities an objective study and practical evidence of innovation ability of university students. The score of the innovation knowledge and innovation personality of the students in the Chinese medicine scientific research class was better than the students in the non Chinese medicine scientific research practice class. The reason lied that the training mode of Chinese medicine research practice class was different from the general classes, including the properties of different disciplines and differences original basis of the university students.

\section{ACKNOWLEDGEMENT}

This research was supported by the College of Humanities and social science fund of Jiangxi Province (XL1415)Teaching Reform Fund of the Education Department of Jiangxi Province (JXJG-14-12-14),Scientific Search Fund of Jiangxi University of Traditional Chinese Medicine(2013RW009) and the Teaching Reform Fund of Jiangxi University of Traditional Chinese Medicine(2013jzyx-12).

\section{REFERENCES}

[1] Wen Cai, Yong Shi. Extension of the scientific significance and future development. Journal of Hal Industrial University. Vol.38(2006),p.1079-1080

[2] Qinzhen Qian, Yongxiang Wang. Multistage application of extension comprehensive evaluation method in the evaluation of green building. Journal of Engineering Management. Vol.02(2014), p.65-67

[3] Information http://www.cnki.com.cn/Article/CJFDTotal-JCGL201402004.htm

on

[4] Haiqi Dai: Psychological and educational measurement (the Third Edition)(Jinan University press, China 2011)

[5] Richang Zhen: Psychological and educational measurement (People's Education Press, China 2011) 